\title{
Multiple sclerosis and herpesvirus interaction
}

\author{
Esclerose múltipla e interação com os herpesvirus \\ Guilherme Sciascia do Olival', Bruna Mendonça Lima', Laura M. Sumita², Vitor Serafim³, \\ Maria Cristina Fink², Luis Henrique Nali², Camila Malta Romano², Rodrigo Barbosa Thomaz', \\ Vitor Breseghello Cavenaghi ${ }^{3}$,Charles Peter Tilbery 4 , Augusto Cesar Penalva-de-Oliveira ${ }^{4}$
}

\begin{abstract}
Multiple sclerosis is the most common autoimmune inflammatory demyelinating disease of the central nervous system, and its etiology is believed to have both genetic and environmental components. Several viruses have already been implicated as triggers and there are several studies that implicate members of the Herpesviridae family in the pathogenesis of MS. The most important characteristic of these viruses is that they have periods of latency and exacerbations within their biological sanctuary, the central nervous system. The Epstein-Barr, cytomegalovirus, human herpesvirus 6 and human herpesvirus 7 viruses are the members that are most studied as being possible triggers of multiple sclerosis. According to evidence in the literature, the herpesvirus family is strongly involved in the pathogenesis of this disease, but it is unlikely that they are the only component responsible for its development. There are probably multiple triggers and more studies are necessary to investigate and define these interactions.
\end{abstract}

Keywords: demyelinating disease, bmultiple sclerosis, herpesvirus.

\section{RESUMO}

A esclerose múltipla é a doença inflamatória auto-imune mais comum do sistema nervoso central. Sua etiologia já foi creditada apresentar tanto causas genéticas quanto ambientais. Vários vírus já foram implicados como desencadeadores desta doença e existem inúmeros trabaIhos fazendo correlação entre a família Herpesviridae e a patogênese da esclerose múltipla. As características mais importantes dos Herpesviridae são as de apresentarem períodos de latência e exacerbação e terem como seu principal santuário biológico o sistema nervoso central. O vírus Epstein-Barr, o citomegalovírus, o herpesvirus tipo 6 e herpesvirus tipo 7 são os membros mais estudados como desencadeadores da esclerose múltipla. Conforme as evidencias que a literatura apresenta a família Herpesviridae está fortemente envolvida na patogênese da esclerose múltipla, porém é pouco provável que sejam os únicos responsáveis pelo seu início. É provável que esta doença apresente inúmeros desencadeadores e mais estudos são necessários para determinar estas interações.

Palavras-Chave: doença desmielinizante, esclerose múltipla, herpesvírus.

\section{The etiology of multiple sclerosis}

Multiple sclerosis (MS) is the most common autoimmune inflammatory disease of the central nervous system (CNS). Even though the underlying mechanisms responsible for the myelin targeted autoimmune attacks on the CNS have been the goal of many studies, a precise etiological agent has yet to be defined. MS has many characteristics of an etiologically complex disease, including heterogeneity, incomplete penetrance, temporal changes, polygenic inheritance, environmental risk factors and genetic predisposition ${ }^{1}$.

There are two main theories that try to explain MS: the genetic and the environmental theories. They interact among each other and are very susceptible to individual variations.
The first theory relies on inherited immune response abnormalities while the second discusses exposure to antigens, trauma, viral infections, and nutritional disorders, among others.

Two hypotheses seek to justify viral causes as the triggers for MS. The first hypothesis suggests that a virus can infect an adult, subsequently increasing his or her chance to develop MS, which wouldn't happen had the infection taken place during childhood. The second hypothesis affirms that trigger pathogens would have higher prevalence in areas with higher MS prevalence. The common point between the two theories is that the age during the first infection determines the population's susceptibility ${ }^{2}$.

\footnotetext{
${ }^{1} \mathrm{MD}$, Neurologist, Irmandade da Santa Casa de Misericórdia de São Paulo, São Paulo SP, Brazil;

${ }^{2}$ Researcher, Virology Laboratory, Universidade de São Paulo, São Paulo SP, Brazil;

${ }^{3}$ Medical Student, Santa Casa de São Paulo, Faculty of Medical Sciences, São Paulo SP, Brazil;

${ }^{4} \mathrm{MD}$, PhD, Full Professor, Santa Casa de São Paulo, Faculty of Medical Sciences, São Paulo SP, Brazil.

Correspondence: Guilherme Sciascia do Olival; Av. Albert Einstein 627 / bloco A1 220; 05651-901 Morumbi São Paulo SP - Brasil;

E-mail: guilhermesolival@gmail.com,guiolival@yahoo.com.br

Study carried out at Hospital da Santa Casa de São Paulo, São Paulo SP, Brazil.
} 
In addition, there are other observations that point to a viral etiology in MS: 1) many viruses are associated with encephalomyelitis and other demyelinating processes; 2) axonal damage, usually associated with CNS viral infections, can precede MS lesions; 3) the T CD8 lymphocytes, involved in viral immunity, are the predominating lymphocytes in the active demyelinating plaques; 4) cortical and axonal damage in the absence of lesions, which are features observed in viral demyelinating processes, are commonly seen in MS; 5) some viruses, including the herpesvirus, have periods of latency and reactivation that resemble the relapsing remitting MS pattern ${ }^{3}$.

Members of the Herpesviridae family, like the EpsteinBarr Virus (EBV), Human Herpes Virus 6 and 7 (HHV-6 and HHV-7) and Cytomegalovirus (CMV) are among the plausible viral agents. Endogenous retroviruses should also be considered as important viral agents in MS.

\section{The Herpesviridae family}

The Herpesviridae family is composed of 8 types of agents, each divided into 3 subfamilies (alpha, beta and gamma). All herpesviruses have 3 basic structural elements: 1- a symmetric nucleocapsid with a diameter of 90 to $110 \mathrm{~nm}$ in the form of an icosahedron which contains the viral DNA, 2- an envelope embedding the viral glycoproteins and 3- the viral tegument consisting of a mix of proteins that occupy the space between the nucleocapsid and the envelope $e^{4}$.

The herpesviridae are capable of staying dormant in the host's organism after first infection due to a latency state in which there is no viral replication or in a state of chronic low level replication. It's important to note that each of these replication states will occur in different sites in the body of the host. While the salivary glands and brain tissue are considered sites of chronic replication, monocytes and bone marrow are considered sites where there is virus latency. It is a very important fact that one of the herpesviridae biological sanctuaries is the $\mathrm{CNS}^{3}$.

\section{Epstein Barr virus and MS}

Certainly the most important herpesvirus related to MS is the EBV. The relation between positive serology to EBV and MS development has been extensively studied. In addition, the effects of EBV within the immune system are undeniable because it maintains a persistent immune response and immortalizes lymphocytes (to a certain point). There have also been a few studies that correlate EBV expression with major MS activity. Finally, the interaction between EBV and endogenous retrovirus has been a recent fascinating field of study.

The EBV was the first virus from the Herpesviridae to be implicated as a possible trigger for MS, in 1971. By that time EBV was a candidate due to some factors: is widely distributed in the nature, establishes a long quiescent infection with continuous viral production, with long periods of reactivation and is capable of modulating the human immune system.

\section{EBV serology and MS development}

The major difficulty in associating MS to the EBV is proving that the infection comes prior to the autoimmune disease. Studying MS pediatric populations was a way to reduce this bias. Pohl et al. presented a study with 147 pediatric MS patients in Europe where the serum prevalence of EBV was of $99 \%$, in comparison with $72 \%$ in the control group $(\mathrm{p}=0.001)^{5}$.

Levin et al. estimated the viral infection time through measures of antibody titers of EBV in serial serum samples collected before MS onset among cases, and on matched dates among controls. They had access to the medical history of approximately 8 million USA Army employees whose blood samples were stored. The case-control study had 305 people that came to develop MS comprising the study group and 610 people comprising the paired control group. Ten individuals from the study group and 32 from the control group were EBV-negative at the beginning. Everyone from the EBVnegative cases of the study group (100\% of the cases) became EBV-positive before the onset of MS in comparison to only $35.7 \%$ in the control group ( $\mathrm{p}=0.0008)^{6}$.

Other research projects also tried to evaluate the relationship between EBV antibodies serum titers and the onset of MS. According to the work of DeLorenze et al., patients with MS already showed a significant elevation of EBV antibodies 20 years before the onset of the first symptoms. It is possible to explain this data in two ways: by the previous existence of an infection that alters the balance of the EBV related T memory cells or by a re-infection caused by a different strain of EBV ${ }^{7}$.

\section{The EBV targeted T lymphocyte response sets up and maintains $M S$}

EBV can infect the B lymphocytes in a very persistent and highly immunogenic way. The T lymphocyte specific antigens are continually produced in increased amounts in response to the first infection and to the chronically high levels of the virus. This autoimmune control is essential to prevent EBV related neoplasm. In its modulating action it is capable of recruiting infected B lymphocytes via expression of latent antigens and helps their differentiation into B memory cells, where the virus persists ${ }^{8}$.

In chronic EBV infections there are strong stimuli to EBVspecific $\mathrm{T}$ lymphocytes. When grown in vitro these cells suppress the production of immunoglobulins by the B cells. Some studies show that patients with autoimmune diseases might have defects in the EBV-specific immunity, such as having a tendency to produce ten times more lysate stimulating interferon.

However it has not been proven if the increase in EBVspecific T CD4 cells is a response to an increase in stimulation by specific myelin antigens identification. The EBV viral load in MS is not very high and the specific $\mathrm{T}$ cells for this virus do not seem to be differentiated from the same cells in hosts without MS9. 


\section{EBV expression is correlated with major MS activity}

During the MS reactivation period there is an increased viral replication period in comparison to the remission period. Patients with early antibody response to EBV antigen are more susceptible to show disease activity, measured through gadolinium nuclear magnetic resonance, than those patients without humoral response. Because of this the disease activity may be related to a latent EBV infection and also is associated with the progression of the disease ${ }^{10}$.

\section{EBV and endogenous retroviruses as emergent associated viruses contributing to MS pathogenesis}

About $8 \%$ of the human genome is constituted by endogenous retroviruses and those have been implicated in many diseases. The activity increase of these viruses may be observed in MS patients. The endogenous retroviruses of the $\mathrm{W}$ family was isolated in the leptomeninges, choroid plexus and cultures of monocytes/macrophages in patients with multiple sclerosis and their origin is still under investigation ${ }^{11-14}$. Our group has recently published the first Brazilian study about the association between MS and Endogenous retrovirus with similar results ${ }^{15}$. The oligodendrocytes are responsible for the myelin production of the central nervous system and can be more sensitive to the endogenous retrovirus than the astrocytes on an animal model that mimics $\mathrm{MS}^{16}$.

A recent study conducted in Sassary, Italy has shown that, in vitro, EBV stimulates the expression of HERV-W in cells deriving from blood and brain. They suggest that in MS pathogenesis, a possible model could include EBV as the initial trigger of future MS, years later, and HERV-W as an actual contributor to MS pathogenicity, in striking parallelism with disease behavior ${ }^{17}$.

\section{Cytomegalovirus and multiple sclerosis}

Studies that correlate levels of antibodies against CMV and MS are controversial. Studies show high rates of CMV infectivity in patients with MS but also a more benign presentation of the disease. Sanadgol et al. collected serum, plasma, peripheral blood mononuclear cells (PBMCs), saliva and urine from MS patients $(n=78)$ and healthy subjects $(n=123)$ and screened for the presence of anti-CMV antibodies and CMV-DNA by nephelometric and PCR methods. Positive results for CMV antibodies were found in $98 \%$ of MS patients compared with $52 \%$ in the control group $(p<0.001)^{18}$. Zivadinov demonstrated that patients who had antibody against CMV had later age of onset, lower rates of reactivation of the disease, and fewer signs of cerebral atrophy on MRI. Those who had higher titers of these antibodies had less brain atrophy and fewer lesions on imaging studies, when compared with patients who had lower titers ${ }^{19}$. Pirko et al., using an animal model to mimic the patterns of MS, demonstrated that animals that had CMV infection before a demyelinating induced disease had milder clinical presentations than those not infected ${ }^{20}$. These studies suggest a beneficial effect of CMV infection by immune response modulation during MS.

\section{Herpes virus type 6 and 7 and multiple sclerosis}

HHV-6 and HHV-7 viruses are closely related and have a similar biologic pattern. These viruses can infect cells of the immune system and modulate their functions. The work described by Nora-Krukle et al. attempted to investigate whether there were associations between HHV-6 and HHV-7 in MS by analyzing the peripheral blood of patients. Patients were randomly selected and divided into two groups: 14 with relapsing remitting multiple sclerosis (RR-MS) and 14 with secondary progressive multiple sclerosis (SP-MS). Among the 28 patients, 25 had latent HHV-6 and/or HHV-7. HHV-6 has been found in 9 patients with RR-MS and 9 with the SP-MS. HHV-7 was found in 10 patients with RR-MS and 14 with the SP-MS ${ }^{21}$.

Opsahl and Kennedy, through the technique of in situ fluorescence hybridization, examined tissues from human cadavers to assess the presence of recent and old HHV-6 viral gene expression in normal brain white matter of MS patients, injured tissue of patients with MS and brain samples of a control group without the disease. The gene transcription of HHV-6 was found in all samples analyzed and was restricted to oligodendrocytes. Quantitative analysis of viral RNA expression showed that in both groups of patients with MS (no brain tissue with abnormal white matter), samples had significantly higher levels of expression of this virus. Furthermore, the tissue lesions presented higher levels of expression of the viral gene, a fact that contributes to the theory that HHV-6 is implicated in the pathogenesis of $\mathrm{MS}^{22}$. The same study methodology using HHV-7 showed no difference between groups ${ }^{23}$. Using all these virus research methods repeatedly, conflicting results can be observed. In fact, when the technologies used were unable to distinguish an active from a latent HHV-6 infection (via analysis of blood leukocytes by PCR and cell liquor containing central nervous system tissue), no difference is found among the samples from patients and control groups. However, when diagnostic technologies are used specifically for detecting the activity of HHV-6 (PCR analysis of acellular specimens, detection of specific IgM antibodies to HHV-6 or immunohistochemical analysis of tissues of the central nervous system), a strong correlation between HHV-6 and pathogenesis of MS is observed ${ }^{24}$. However, it is important emphasize that HHV-7 has little evidence supporting its correlation MS.

\section{Conclusion}

Undoubtedly, MS is an extremely complex disease. The heterogeneity of symptoms, its multiple presentations and 
its patterns of symptoms are highly variable from person to person. This enormous variation is the reason why some patients are already much debilitated in the beginning of the disease while others keep living their lives normally.

Apart from its vast spectrum of symptoms this disease is of utter importance due to its imense socioeconomic impact. The etiology of MS has been thoroughly studied yet not one single etiology has been defined. A viral trigger was suggested over 100 years ago and, since then, several viruses have been appointed as possible candidates.

The main hypothesis is that there is no isolated factor as a cause for MS but a myriad of them acting together and in different ways on each individual, associated with genetic susceptibility. More studies are needed in an attempt to confirm this hypothesis and permit possible interventions that may minimize the effects of such interactions.

\section{References}

1. Zuvich RL, Mccauley JL, Pericak-Vance MA, Haines JL. Genetics and pathogenesis of multiple sclerosis. Sem Immunol 2009; 21:328-333.

2. Ascherio A, Munger KL. Environmental risk factors for multiple sclerosis. Part I: the role of infection. Ann Neurol 2007;61:288-299.

3. Voumvourakis KI, Dimitrios KK, Tsiodras S, Petrikkos G, Stamboulis E. Human herpesvirus 6 infection as a trigger of multiple sclerosis. Mayo Clin Proc 2010;85:1023-1030.

4. De Bolle L, Naesens L, De Clercq E. Update on human herpesvirus 6 biology, clinical features and therapy. Clin Microbiol Rev 2005;18:217-245.

5. Pohl D, Krone B, Rostasy K. High seroprevalence of Epstein-Barr virus in children with multiple sclerosis. Neurology 2006;67:2063-2065.

6. Levin LI, Munger K, O’Reilly EJ, Falk KI, Ascherio A. Primary infection with Epstein-Barr virus and risk of multiple sclerosis. Ann Neurol 2010;67:824-830.

7. De Lorenze GN, Munger KL, Lennette ET, Orentreich N, Vogelman JH, Ascherio A. Epstein-Barr virus and multiple sclerosis: evidence of association from a prospective study with long-term follow-up. Arch Neurol 2006;63:839-844.

8. Ascherio A, Munger KL, Lennette ET, et al. Epstein-Barr virus antibodies and risk of multiple sclerosis. J Am Med Assoc 2001; 286:3083-3088.

9. Lünemann JD, Kamradt T, Martin R, Münz C. Epstein-Barr virus: environmental trigger of multiple sclerosis? J Virol 2007;81:6777-6784.

10. Giovannoni G. Epstein-Barr virus and MS. Internat MS J 2011;17:44-49.

11. Dolei A, Serra C, Mameli G, et al. Multiple sclerosis associated retrovirus (MSRV) in Sardinian MS patients. Neurology 2002;58:471-473.

12. Serra C, Sotgiu S, Mameli G, Pugliatti M, Rosati G, Dolei A. Multiple sclerosis and multiple sclerosis associated retrovirus in Sardinia. Neurol Sci 2001;22:171-173.

13. Sotgiu S, Serra C, Mameli G. Multiple sclerosis associated retrovirus and MS prognosis: an observational study. Neurology 2002;5:1071-1073.

14. Perron H, Garson JA, Bedin F. Molecular identification of a novel retrovirus repeatedly isolated from patients with multiple sclerosis.
The Collaborative Research Group on Multiple Sclerosis. Proc Natl Acad Sci U S A 1997;14:7583-7588.

15. do Olival GS, Faria TS, Nali LH, et al. Genomic analysis of ERVWE2 locus in patients with multiple sclerosis: absence of genetic ssociation but potential role of human endogenous retrovirus type $\mathrm{W}$ elements in molecular mimicry with myelin antigen. Front Microbiol 2013;4:172.

16. Antony JM, Van Marle G, Opii W. Human endogenous retrovirus glycoprotein-mediated induction of redox reactants causes oligodendrocytes death and demyelination. Nature Neurosc 2004;7: 1088-1095.

17. Mameli G, Poddighe L, Mei A, et al. Expression and activation by Epstein Barr virus of human endogenous retroviruses-W in blood cells and astrocytes: inference for multiple sclerosis. PLoS One 2012;7:e44991.

18. Sanadgol N, Ramroodi N, Ahmadi GA, et al. Prevalence of cytomegalovirus infection and its role in total immunoglobulin pattern in Iranian patients with different subtypesof multiple sclerosis. New Microbiol 2011;34:263-274.

19. Zivadinov R, Nasuelli D, Tommasi MA, Serafin M, Bratina A. Positivity of cytomegalovirus antibodies predicts a better clinical and radiological outcome in multiple sclerosis. J Neurol Res 2006;28:262-269.

20. Pirko I, Cardin R, Chen Y, et al. CMV infection attenuates the disease course in a murine model of multiple sclerosis. PLOS ONE 2012;7:1-7.

21. Nora-Krunkle Z, Chapenko S, Logina I, Millers A, Platkajis A, Murovska M. Human herpesvirus 6 and 7 and disease activity in multiple sclerosis. Medicina (Kaunas) 2011;47:527-531.

22. Opsahl ML, Kennedy PG. Early and late HHV-6 gene transcripts in multiple sclerosis lesions and normal appearing white matter. Brain 2005;128:516-527.

23. Opsahl ML, Kennedy PG. Investigating the presence of human herpesvirus 7 and 8 in multiple sclerosis and normal control brain tissue. J Neurol Sci 2006;240:37-44.

24. Knox KK, Brewer JH, Henry JM, Harrington DJ, Carrigan DR. Human herpesvirus 6 and multiple sclerosis: systemic active infections in patients with early disease. Clin Infect Dis 2000;31:894-903. 